\title{
Norcantharidin suppresses cell growth and migration with enhanced anticancer activity of gefitinib and cisplatin in human non-small cell lung cancer cells
}

\author{
YA-CHUN LEE ${ }^{1 *}$, LIANG-MING LEE ${ }^{2 *}$, CHIH-HSIN YANG ${ }^{3}$, ANYA MAAN-YUH LIN $^{1,4}$, \\ YI-CHIA HUANG ${ }^{1}$, CHIA-CHI HSU ${ }^{1}$, MENG-SHIAN CHEN ${ }^{1}$, CHIN-WEN CHI ${ }^{1,4}$, \\ PEN-HUI YIN ${ }^{4}$, CHENG-DENG KUO $^{4}$, JYH-FEI LIAO $^{1 * *}$ and HSIN-CHEN LEE ${ }^{1 * *}$
}

\author{
${ }^{1}$ Department and Institute of Pharmacology, School of Medicine, National Yang-Ming University; ${ }^{2}$ Department of Urology, \\ Taipei Medical University-Affiliated Taipei Municipal Wan-Fang Hospital; ${ }^{3}$ Department of Oncology, National Taiwan \\ University Hospital; ${ }^{4}$ Department of Medical Research and Education, Taipei Veterans General Hospital, Taipei, Taiwan, R.O.C.
}

Received July 17, 2012; Accepted September 7, 2012

DOI: $10.3892 /$ or.2012.2118

\begin{abstract}
Norcantharidin is the demethylated analog of cantharidin isolated from blister beetles (Mylabris phalerata Pall.). In this study, we evaluated whether norcantharidin exhibits anticancer effects against the human non-small cell lung cancer cell lines A549 (epidermal growth factor receptor (EGFR) mutation-negative) and PC9 (EGFR mutation-positive). Our results revealed that norcantharidin dose-dependently retards cell growth, arrests cell cycle at $\mathrm{G}_{2} / \mathrm{M}$ phase, reduces cell migration, and even induces apoptosis at the concentration of $100 \mu \mathrm{M}$. Moreover, we found that norcantharidin enhances the anticancer effects of gefitinib and cisplatin. Norcantharidin exhibited similar potency of anticancer effects against the two cell lines with different EGFR mutation status and did not affect EGF-induced EGFR phosphorylation, suggesting that the EGFR signaling may not be the target of norcantharidin. In conclusion, our results suggest that norcantharidin exhibits anticancer effects against non-small cell lung cancer cells in vitro and support its potential as a chemotherapeutic agent for treating non-small cell lung cancer.
\end{abstract}

\section{Introduction}

Despite recent advances in diagnosis and treatment, lung cancer remains the leading cause of cancer death in males

Correspondence to: Professor Hsin-Chen Lee or Professor Jyh-Fei Liao, Department and Institute of Pharmacology, School of Medicine, National Yang-Ming University, No. 155, Sec. 2, Li-Nong St., Peitou, Taipei, Taiwan, R.O.C.

E-mail: hclee2@ym.edu.tw and jfliao@ym.edu.tw

${ }^{*}$ Contributed equally; ${ }^{* *}$ Shared senior authorship

Key words: norcantharidin, lung cancer, epidermal growth factor receptor and the second leading cause of cancer death in females in the world (1). Non-small cell lung cancer (NSCLC) is the most prevalent and accounts for $80 \%$ of lung cancers, and patients usually present in the advanced stages with poor prognosis and difficulty in management. As for primary chemotherapy, advanced NSCLC is often treated with cisplatin or carboplatin, in combination with gemcitabine, paclitaxel, docetaxel, etoposide, or vinorelbine (2). The platinum-based chemotherapy was also adopted as standard use of adjuvant chemotherapy for NSCLC. However, the toxicity to normal cells largely reduced the success of the platinum-based chemotherapy.

The epidermal growth factor receptor (EGFR) is a promising target for anticancer therapy due to its expression or overexpression in a variety of tumors, including NSCLC (3). High levels of EGFR expression and dysregulation might promote tumor growth by increasing cell proliferation, motility, invasive capacity or by evading apoptosis, which were thus associated with poorer prognosis (4). Recently, gefitinib was indicated for the treatment of adult patients with locally advanced or metastatic NSCLC with activating mutations of the tyrosine kinase domain of EGFR $(5,6)$. EGFR mutation-positive patients have better efficacy outcomes with first-line gefitinib when compared with those who are EGFR mutation-negative. In addition to the EGFR mutation status of the patients, several adverse drug reactions largely limited the use of the EGFR-target therapy $(7,8)$. Thus, there is an urgent need to identify new therapeutic agents for alternative treatments or combination therapies for lung cancer.

Norcantharidin is the demethylated analog of cantharidin isolated from blister beetles (Mylabris phalerata Pall.). Norcantharidin was reported to possess anticancer activity but less nephrotoxicity than cantharidin (9). There is accumulating evidence that norcantharidin inhibits the proliferation of a variety of human tumor cell lines (10-12), induces apoptosis $(10,13,14)$, suppresses the invasion and metastasis (15), inhibits angiogenesis (16), represses tumor growth in animals $(17,18)$. However, few studies have reported the anticancer effect of norcantharidin against human lung cancer cells.

In this study, we evaluated whether norcantharidin exhibits anticancer effects against the human lung cancer cell lines, 
A549 (EGFR mutation-negative) and PC9 (EGFR mutationpositive), and determined the effects of combination treatments with gefitinib and cisplatin, respectively. In addition, since norcantharidin has been reported as a protein phosphatase 1 (PP1) and protein phosphatase 2A (PP2A) inhibitor (19-21), the roles of the norcantharidin-activated signaling pathways will be further discussed.

\section{Materials and methods}

Chemicals and antibodies. Norcantharidin and cisplatin were purchased from Sigma-Aldrich (St. Louis, MO, USA). Epidermal growth factor (EGF) was purchased from R\&D Systems, Inc. (Minneapolis, MN, USA). Gefitinib was provided by Astra Zeneca. Antibodies against the cdc25C, the cyclin B1, the cyclin-dependent kinase 1 (cdk1), and phospho-specific EGFR antibodies (pY1068, pS1046/1047, pY1148, pY1173) were purchased from Cell Signaling Technology, Inc. (Danvers, MA, USA). Antibody against the EGFR (sc-03) was purchased from Santa Cruz Biotechnology, Inc. (Santa Cruz, CA, USA). Antibody against the $\alpha$-tubulin was purchased from Sigma-Aldrich.

Cell culture. Human lung cancer cell lines A549 and PC9 were cultured at $37^{\circ} \mathrm{C}$ in $5 \% \mathrm{CO}_{2}$ in RPMI-1640 medium supplemented with $10 \%$ FBS (Hyclone), $50 \mathrm{U} / \mathrm{ml}$ penicillin $\mathrm{G}$, and $50 \mathrm{mg} / \mathrm{ml}$ streptomycin sulfate.

Trypan blue exclusion assay. Cells $\left(1 \times 10^{5}\right)$ were seeded in 6-well cell culture cluster (Costar, Cambridge, MA, USA) overnight and then treated with different concentrations of norcantharidin $(0,12.5,25$ and $100 \mu \mathrm{M})$, respectively. After treatment for 24 to $72 \mathrm{~h}$, cells were harvested by trypsin-EDTA and the cell pellet was resuspened in culture medium containing $0.04 \%$ trypan blue and the viable cells were counted by a hemocytometer.

MTT assay. Cells were seeded in a 24-well cell culture cluster (Costar) at a density of $2 \times 10^{4}$ cells per $\mathrm{ml}$ and cultured overnight prior to drug treatment. After norcantharidin treatment for $48 \mathrm{~h}$, the medium was discarded and replaced with an equal volume $(0.5 \mathrm{ml})$ of fresh medium containing $0.456 \mathrm{mg} / \mathrm{ml}$ 3-[4,5-dimethylthiazol-2-yl]-2,5-diphenyl-tetrazolium bromide (MTT; Sigma Chemical Co., St. Louis, MO, USA) and incubated for $1 \mathrm{~h}$ at $37^{\circ} \mathrm{C}$ in the dark. The medium was discarded, and cells were combined with $100 \mu 1$ dimethyl sulfoxide (DMSO) (Sigma Chemical Co.) to dissolve the formazan produced. Cell viability was determined according to the colorimetric comparison by reading optical density (OD) values from a microplate reader (Spectra Max 250; Spectra Diode Laboratories, Inc., San Jose, CA, USA) at an absorption wavelength of $570 \mathrm{~nm}$.

Western blotting. Cells were scraped from 10-cm dishes and suspended in RIPA lysis buffer (980 $\mu \mathrm{l}$ RIPA, $5 \mu$ l aprotinin, $5 \mu \mathrm{l}$ PMSF, $5 \mu \mathrm{l}$ EGTA and $5 \mu \mathrm{l} \mathrm{Na}_{3} \mathrm{VO}_{4}$ ) on ice. Collected cells were fractured by sonication on ice and then centrifuged at $10,000 \mathrm{x} \mathrm{g}$, at $4^{\circ} \mathrm{C}$ for $15 \mathrm{~min}$. The protein concentration was determined using Bradford reagent and then $30 \mu \mathrm{g}$ of extracted protein in $4.5 \mu \mathrm{l}$ of sample buffer $(1.6 \mathrm{ml} 1.25 \mathrm{M}$ Tris- $\mathrm{HCl}, 3.2 \mathrm{ml}$ glycerol, $0.64 \mathrm{~g}$ SDS, $1.6 \mathrm{ml} \beta$-mercaptoethanol, $0.8 \mathrm{ml} 0.5 \%$

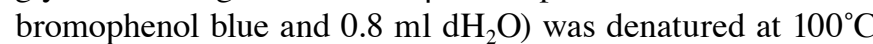
for $10 \mathrm{~min}$. Proteins were separated by $8 \%$ SDS-PAGE and then electrophoretically transferred to a nitrocellulose membrane. Subsequently, the membranes were incubated in the presence of different primary antibodies at $4^{\circ} \mathrm{C}$ overnight and then the membrane was incubated with different secondary antibodies at $37^{\circ} \mathrm{C}$ for $1 \mathrm{~h}$. Finally, ECL solution was used for antibody binding and chemiluminescence of the membrane. All results shown are representative of at least two separate experiments.

Cell cycle analysis and determination of apoptotic cells in sub-G1 phase. Procedures were carried out according to previously reported methods (22). In brief, after treatment with norcantharidin for $48 \mathrm{~h}$, the cells were trypsinized and resuspended in $70 \%$ ethanol, the cells were then incubated on ice for at least $1 \mathrm{~h}$ and resuspended in $1 \mathrm{ml}$ of cell cycle assay buffer $(0.38 \mathrm{mM}$ sodium citrate, $0.5 \mathrm{mg} / \mathrm{ml}$ RNase A, and $14.9 \mu \mathrm{M}$ propidium iodide) at a concentration of $5 \times 10^{5}$ cells $/ \mathrm{ml}$. Samples were stored in the dark at $4^{\circ} \mathrm{C}$ until cell cycle analysis, which was carried out using a flow cytometer and ModFit LT 2.0 software (Verity Software, Topsham, ME).

Flow cytometry analysis. A FACS Calibur flow cytometer (Becton Dickinson, Bedford, MA) equipped with a 488-nm argon laser was used for the flow cytometric analysis. Forward and side scatters were used to establish size gates and exclude cellular debris from the analysis. The excitation wavelength was set at $488 \mathrm{~nm}$. In each measurement, a minimum of 15,000 cells were analyzed. Data were acquired and analyzed using the Cell Quest software (Becton Dickinson). Relative change in the mean fluorescence intensity was calculated as the ratio between mean fluorescence intensity in the channel of the treated cells and that of the control cells.

Transwell migration assay. Transwell migration assay was carried out with a 24-well chamber (Costar 3422, Corning Inc., Corning, NY). The lower and upper chambers were separated by a polycarbonate membrane $\left(8 \mu \mathrm{m}\right.$ pore size). Cells $\left(1 \times 10^{5}\right)$ were resuspended in RPMI medium containing $1 \%$ FBS in the upper chamber. The RPMI medium containing $20 \%$ FBS was added to the lower chamber. Cells were allowed to migrate for $10 \mathrm{~h}$ (A549 cells) or $16 \mathrm{~h}$ (PC9 cells) at $37^{\circ} \mathrm{C}$ in a humidified atmosphere containing $5 \% \mathrm{CO}_{2}$. The membrane was fixed in methanol for $20 \mathrm{~min}$ at $4^{\circ} \mathrm{C}$, and then stained with Liu's stain A for $5 \mathrm{~min}$ and Liu's stain B for $30 \mathrm{~min}$. Cells on the upper side of the membrane were removed by PBS-rinsed cotton swabs. Cells on the lower side of the membrane were counted under a light microscope with the 10X objective lens. Two individuals blinded to the treatment of the transwell filter counted cells from four random fields in each of two wells per treatment; and the results were pooled. Each experiment was performed in triplicate.

Immunofluorescence and fluorescence microscopic analysis. Cells were fixed using $3.7 \%$ formaldehyde for $20 \mathrm{~min}$ at room temperature and then washed with PBS and wash buffer $(0.1 \%$ BSA in PBS). After incubation in blocking buffer (5\% BSA and $0.3 \%$ Triton X-100 in PBS) for 45 min at room temperature, the fixed cells were stained for F-actin with $2 \mathrm{U} / \mathrm{ml}$ Oregon Green 488 phalloidin (Molecular Probes, Eugene, OR, USA) for $30 \mathrm{~min}$ and then stained for DNA with $0.2 \mu \mathrm{g} / \mathrm{ml}$ 4',6-Diamidino-2-phenylindole (DAPI) for $10 \mathrm{~min}$. The images 

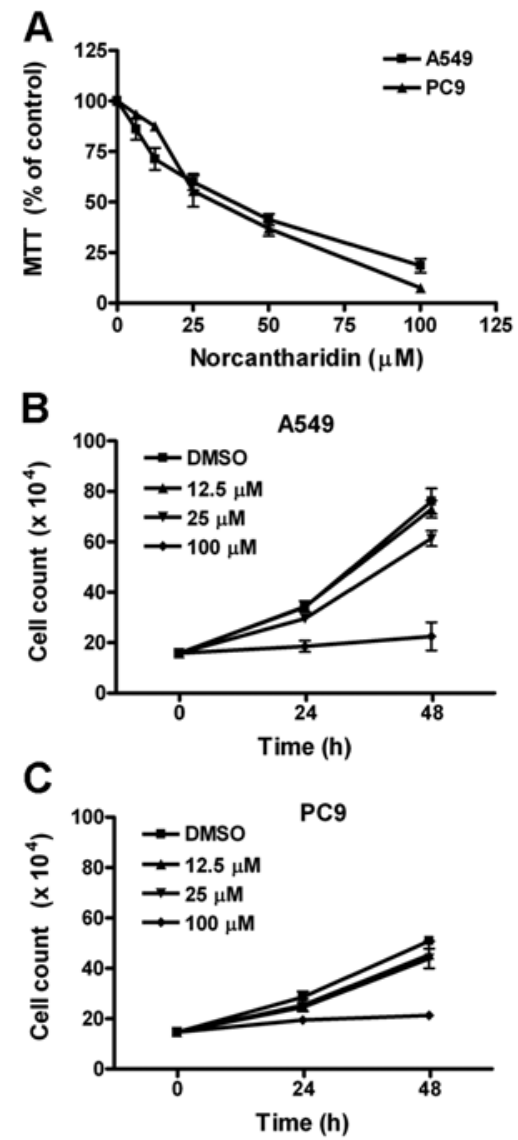

Figure 1. Norcantharidin inhibits cell growth. (A) Human lung cancer cell lines A549 and PC9 cells were treated with control (DMSO), or 6.25, 12.5, 25, $50,100 \mu \mathrm{M}$ norcantharidin for $48 \mathrm{~h}$, respectively. Viable cells were analyzed using MTT assay as described in Materials and methods. Values are means \pm SEM of results from three independent experiments in triplicate. The A549 (B) and PC9 (C) cells were treated with control (DMSO), or 12.5, 25, $100 \mu \mathrm{M}$ norcantharidin for 24 and $48 \mathrm{~h}$. Viable cells were counted using trypan blue exclusion assay as described in Materials and methods. Values are means \pm SEM of results from two independent experiments in duplicate.

were recorded by an Olympus IX70 fluorescence microscope (Olympus America Inc., Melville, NY, USA). Cells from ten random fields in each treatment experiment were counted and the ratio of the cells with bi-nucleus was calculated. Each experiment was performed in triplicate.

Statistics. Data are shown as the mean \pm SEM except where indicated. Statistical comparison of data between groups were performed using one-way analysis of variance (ANOVA), followed by Student's t-test. A p-value $<0.05$ is considered statistically significant.

\section{Results}

Norcantharidin retards cell growth of human lung cancer cells. Using MTT assay, we first evaluated the effect of norcantharidin on cell proliferation of two human lung cancer cell lines A549 and PC9. After treatments with 6.25, 12.5, 25, 50 and $100 \mu \mathrm{M}$ norcantharidin for $48 \mathrm{~h}$, the MTT values were dose-dependently decreased (Fig. 1A). The IC50 for A549 and PC9 cells were $29.3 \pm 2.9 \mu \mathrm{M}$ and $31.0 \pm 1.8 \mu \mathrm{M}$, respectively. Using trypan blue exclusion assay, we further counted the number of survived cells
A Norcantharidin $(\mu \mathrm{M})$
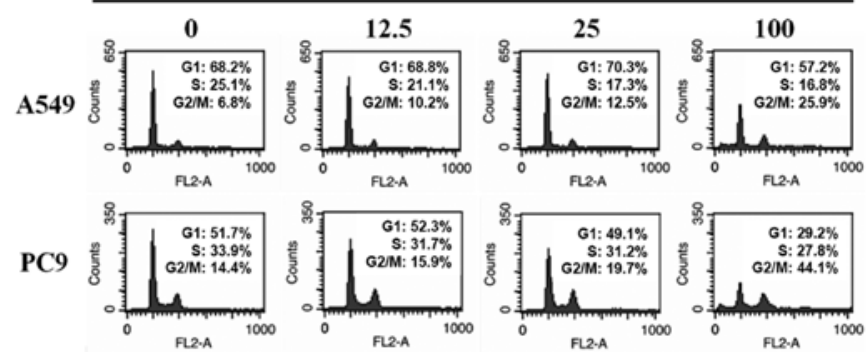

B

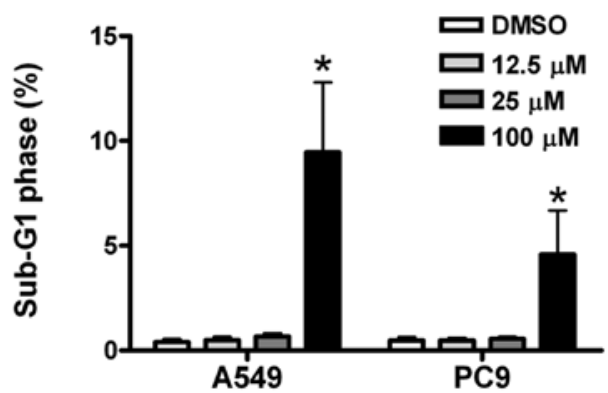

Figure 2. Norcantharidin inhibits cell cycle and induces apoptosis. (A) The A549 and PC9 cells were treated with $0,12.5,25$ and $100 \mu \mathrm{M}$ norcantharidin for $48 \mathrm{~h}$. The distribution of cell cycle was analyzed using PI staining and flow cytometry analysis as described in Materials and methods. Values are means \pm SEM of results from three independent experiments in triplicate. (B) The A549 and PC9 cells were treated with $0,12.5,25$ and $100 \mu \mathrm{M}$ norcantharidin for $48 \mathrm{~h}$. The proportion of the cells at sub-G1 phase was assessed using PI staining and flow cytometry analysis as described in Materials and methods. Values are means \pm SD of results from three independent experiments in triplicate. (" $\mathrm{p}<0.05$, as compared to each control, $0 \mu \mathrm{M}$ norcantharidin).

under treatments with $12.5,25$ and $100 \mu \mathrm{M}$ norcantharidin for 24 and $48 \mathrm{~h}$, respectively. Both Fig. 1B and C show that norcantharidin, especially at $100 \mu \mathrm{M}$, inhibited the increase in survived cell count of A549 and PC9 cells. These results indicated that norcantharidine suppressed cell growth of the two human lung cancer cell lines studied.

Norcantharidin inhibits cell cycle and induces cell death. We analyzed the changes of cell cycle distribution of the two lung cancer cell lines treated with $12.5,25$ and $100 \mu \mathrm{M}$ norcantharidin for $48 \mathrm{~h}$, respectively. The results revealed that the proportions of the treated cells at $\mathrm{G}_{2} / \mathrm{M}$ phase were increased in a dose-dependent manner (Fig. 2A). Moreover, the proportions of sub-G1 phase cells were increased in the two lung cancer cell lines after $100 \mu \mathrm{M}$ norcantharidin treatment for $48 \mathrm{~h}$ (Fig. 2B).

Using DAPI to stain the nucleus and phalloidin to stain F-actin, we found that treatments with 25 and $100 \mu \mathrm{M}$ norcantharidin for $48 \mathrm{~h}$ significantly increased the proportions of the bi-nucleated cells in the A549 (Fig. 3A) and PC9 cells (Fig. 3B) as compared with the untreated cells. Fig. $3 \mathrm{C}$ shows that the increased extents of the bi-nucleated proportion of the A549 cells were higher than those of the PC9 cells. Using western blotting, we further determined the protein contents of the cdc25, cyclin B1 and cdk1, the important regulators at the $\mathrm{G}_{2} / \mathrm{M}$ check point, and found that the three protein levels were obviously decreased in the $\mathrm{A} 549$ cells after $12.5,25$ and $100 \mu \mathrm{M}$ norcantharidin treatment for $48 \mathrm{~h}$; and the decrease in the PC9 cells was significant 


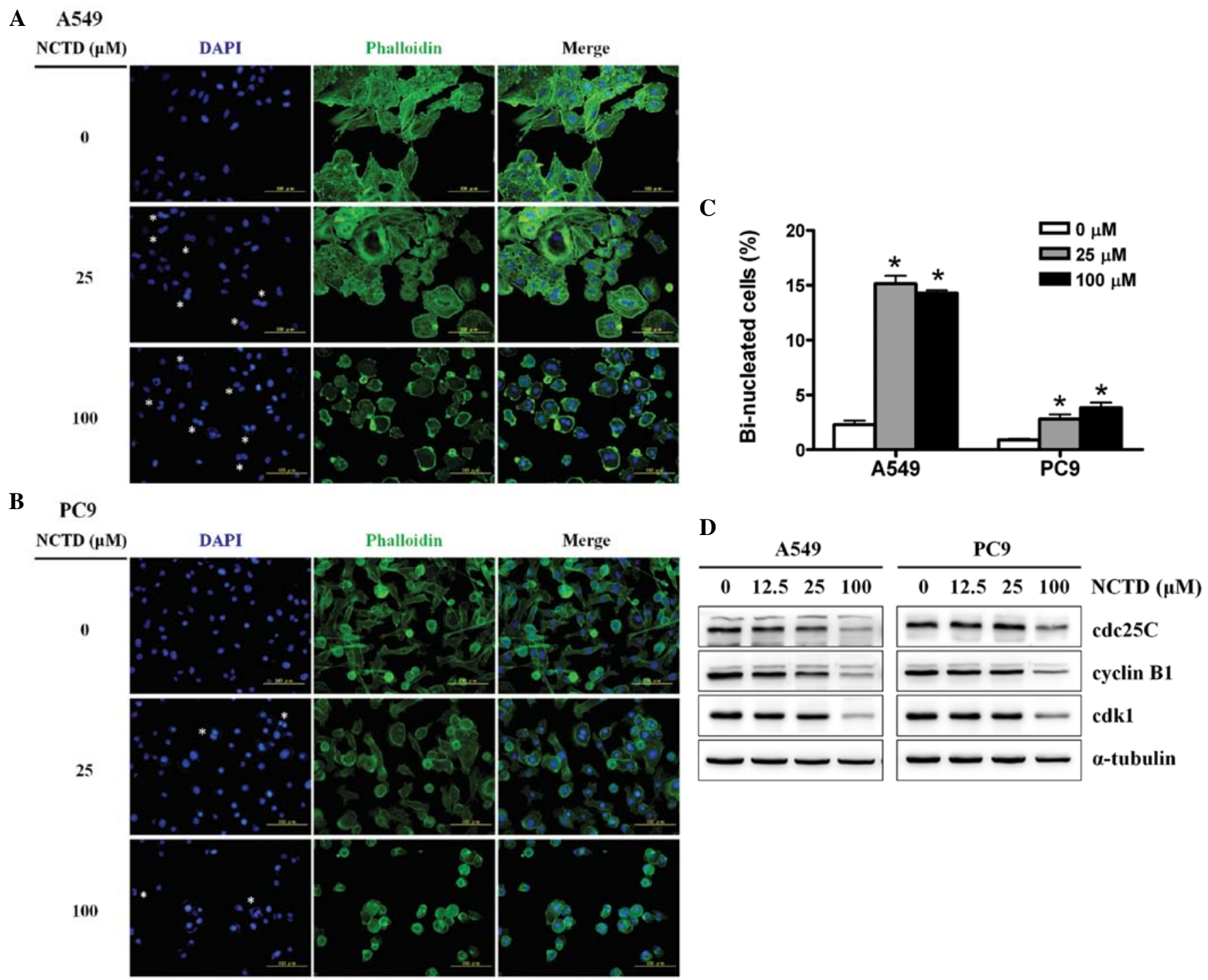

Figure 3. Norcantharidin retards cell cycle at $\mathrm{G}_{2} / \mathrm{M}$ phase. The A549 (A) and PC9 (B) cells were treated with 0,25 , and 100 $\mu \mathrm{M}$ norcantharidin (NCTD) for $48 \mathrm{~h}$. The cells were fixed and stained with fluorescent Oregon Green phalloidin for staining F-actin and DAPI for staining DNA. The images were recorded by a fluorescence microscope. Asterisk (*) indicates the cell with bi-nucleus. (C) Cells from ten random fields in each treatment experiment were counted and the ratio of the cells with bi-nucleus was calculated. Values are means \pm SEM of results from three independent experiments in triplicate. Data were analyzed using Student's t-test. ( ${ }^{*} \mathrm{p}<0.05$, as compared to each control, $0 \mu \mathrm{M}$ norcantharidin) (D). The A549 and PC9 cells were treated with 0,25 , and $100 \mu \mathrm{M}$ norcantharidin for $48 \mathrm{~h}$. The protein contents of the cdc25, cyclin B1, cdk1, and $\alpha$-tubulin were determined using western blotting. Consistent results from three independent experiments were observed.

at the norcantharidin concentration of $100 \mu \mathrm{M}$ (Fig. 3D). These results suggested that norcantharidin caused cell cycle arrest at $\mathrm{G}_{2} / \mathrm{M}$ phase and high dose of norcantharidin induced cell death of the two human lung cancer cell lines.

Norcantharidin represses cell migration. Using transwell cell migration assay, we evaluated whether or not norcantharidin affects the migration ability of the human lung cancer cells. The relatively low concentrations of norcantharidin (12.5 and $25 \mu \mathrm{M}$, respectively) were used for the experiments due to their minor effects on cell survival during the first $10 \mathrm{~h}$ exposures for the A549 cells (Fig. 1B) and the first $16 \mathrm{~h}$ exposures for the PC9 cells (Fig. 1C). We found that norcantharidin dosedependently reduced the migration ability of the two cancer cell lines studied (Fig. 4).

Norcantharidin enhanced anticancer effects of gefitinib and cisplatin. We further examined whether norcantharidin can enhance the cytotoxic effect of anticancer drugs against human lung cancer cells. Gefitinib is one of tyrosine kinase inhibitors and has been clinically used for lung cancer patients. For the two human lung cancer cell lines, A549 cells were more resistant to gefitinib than PC9 cells (Fig. 5A). We found that combined treatment with $10 \mu \mathrm{M}$ gefitinib, $6.25 \mu \mathrm{M}$ norcantharidin can significantly enhance the cytotoxic effect of gefitinib against the A549 cells (Fig. 5B). Similarly, combined treatment with $0.02 \mu \mathrm{M}$ gefitinib, $6.25 \mu \mathrm{M}$ norcantharidin can significantly enhance the cytotoxic effect of gefitinib against the gefitinib-sensitive PC9 cells (Fig. 5C).

A549 and PC9 were shown to have similar sensitivity to cisplatin (Fig. 6A). We found that combined treatment with $0.5 \mu \mathrm{M}$ cisplatin, $6.25 \mu \mathrm{M}$ and $25 \mu \mathrm{M}$ norcantharidin significantly enhanced the cytotoxic effect of cisplatin against the A549 cells (Fig. 6B). Moreover, when combined with $0.1 \mu \mathrm{M}$ cisplatin, norcantharidin significantly enhanced the cytotoxic effect of cisplatin against the PC9 cells (Fig. 6C). These results 
A

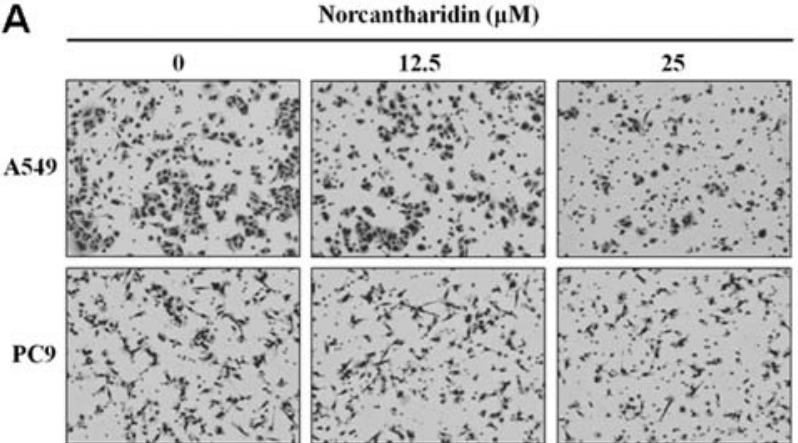

B

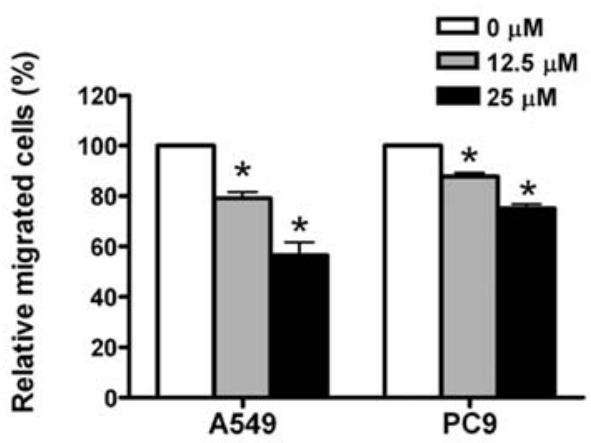

Figure 4. Norcantharidin suppresses cell migration. (A) Cell migration was analyzed using the transwell migration assay as described in Materials and methods. The $1 \times 10^{5}$ of A549 and PC9 cells were, respectively, seeded in the upper chamber containing RPMI medium and $1 \%$ FBS as well as $0,12.5$, and $25 \mu \mathrm{M}$ norcantharidin. The lower chamber contained RPMI medium and $20 \%$ FBS. After incubated for $10 \mathrm{~h}$ for A549 cells and $16 \mathrm{~h}$ for PC9 cells, the migrated cells were fixed and stained. (B) The migrated cells from four random fields in each of two wells per treatment were counted and the results were pooled. The relative migrated cells were shown as compared with that of $0 \mu \mathrm{M}$ norcantharidin (control). Values are means \pm SEM of results from three independent experiments in duplicate. Data were analyzed using Student's t-test;. " $\mathrm{p}<0.05$, as compared to each control, $0 \mu \mathrm{M}$ norcantharidin.

indicated that norcantharidin enhanced the anticancer effects of gefitinib and cisplatin against human lung cancer cells.

Norcantharidin does not alter phosphorylation status of EGFR. Mutations that lead to EGFR upregulation or overactivity are often associated with human lung cancer. Since signaling through EGFR is a key regulator in proliferation and migration of lung cancer cells, we hypothesized that EGFR could be involved in the norcantharidin-induced cytotoxicity of human lung cancer cells. To test this hypothesis, we examined the effect of norcantharidin on the phosphorylation status of EGFR. After serum starvation for $24 \mathrm{~h}$, treatment with $25 \mathrm{ng} /$ $\mathrm{ml}$ EGF for $1 \mathrm{~h}$ can significantly increase phosphorylation of EGFR at pS1046/1047, pY1068, pY1148, and pY1173 sites of the A549 (Fig. 7A) and PC9 cells (Fig. 7B). Of note, treatments with $6.25,12.5,25,50$, and $100 \mu \mathrm{M}$ norcantharidin did not significantly change the phosphorylation status of all examined phosphorylation sites of EGFR in the two cell lines (Fig. 7). The results suggested that EGFR could not be involved in the norcantharidin-induced cytotoxicity of human lung cancer cells.

\section{Discussion}

In this study, we found that norcantharidin exhibits anticancer effects against human lung cancer cell lines A549 (EGFR
A

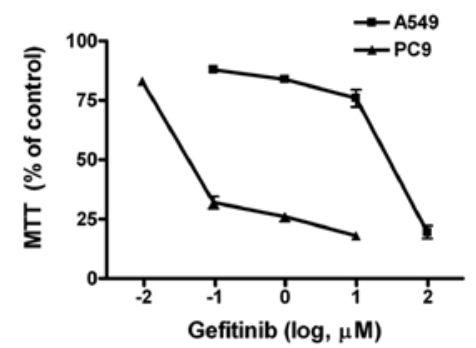

B

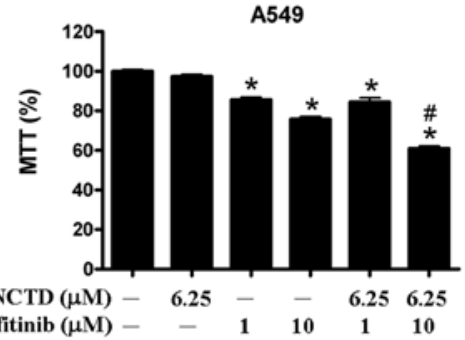

C

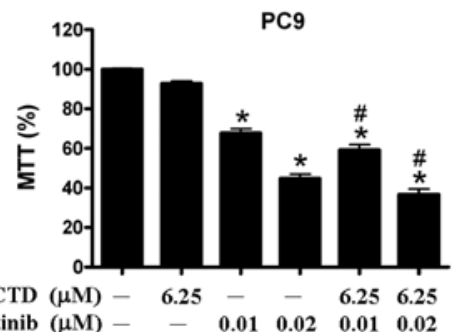

Figure 5. Norcantharidin enhances the cyctotoxicity of gefitinib against A549 cells. (A) The A549 and PC9 cells were treated without or with 0.01, 0.1, 1, 10 , and $100 \mu \mathrm{M}$ gefitinib for $48 \mathrm{~h}$. Viable cells were analyzed using MTT assay as described in Materials and methods. Values are means \pm SEM of results from three independent experiments in triplicate. (B) The A549 cells were treated 1 and $10 \mu \mathrm{M}$ gefitinib combined with or without $6.25 \mu \mathrm{M}$ norcantharidin (NCTD) for $48 \mathrm{~h}$. Viable cells were analyzed using MTT assay as described in Materials and methods. Values are means \pm SD of results from three independent experiments in triplicate. (C) The PC9 cells were treated 0.01 and $0.02 \mu \mathrm{M}$ gefitinib combined with or without $6.25 \mu \mathrm{M}$ norcantharidin for $48 \mathrm{~h}$. Viable cells were analyzed using MTT assay as described in Materials and methods. Values are means \pm SEM of results from three independent experiments in triplicate. Data were analyzed using Student's t-test; ${ }^{*} \mathrm{p}<0.05$, as compared to the value of control; ${ }^{\#} \mathrm{p}<0.05$, as compared to the value of gefitinib treatment alone at corresponding concentration.

mutation-negative) and PC9 (EGFR mutation-positive), including cell growth inhibition, cell cycle arrest at $\mathrm{G}_{2} / \mathrm{M}$ phase, cell migration reduction, and even apoptosis when the concentration is high. Our findings are consistent with the previous studies in various cancers $(10-12,15,16,23)$. Notable, we demonstrated that norcantharidin enhances the anticancer effects of gefitinib and cisplatin, respectively. Our results suggested the potential for norcantharidin as a chemotherapeutic agent for treating lung cancer.

Inhibition of cell growth induced by norcantharidin might be associated with disturbance of cell cycle progression of the lung cancer cells. Norcantharidin increased the cell proportion at the $\mathrm{G}_{2} / \mathrm{M}$ phase (Fig. 2A), the number of bi-nuclear cells (Fig. 3C), and reduced the protein contents of the important regulators at the $\mathrm{G}_{2} / \mathrm{M}$ check point (cdc25, cyclin B1 and cdk1, Fig. 3D), suggesting that norcantharidin might retard the cell cycle at the $\mathrm{G}_{2} / \mathrm{M}$ phase. The results are consistent with previous findings in human glioblastoma (24), hepatoma cells (10), leukemic Jurkat T cells (25) and breast cancer cells (26), 
A

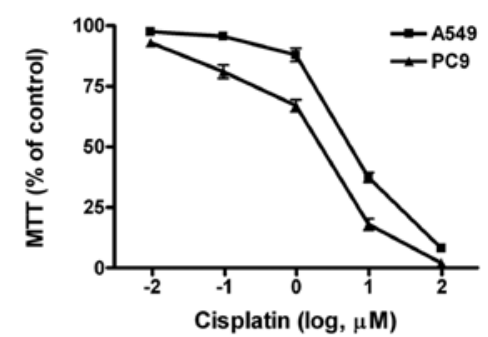

B

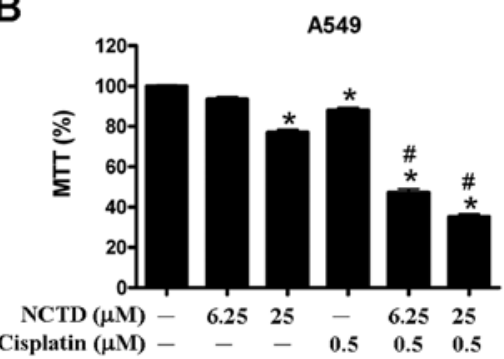

C

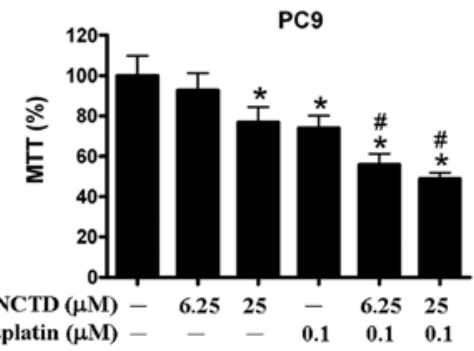

Figure 6. Norcantharidin enhances the cyctotoxicity of cisplatin against lung cancer cells. (A) The A549 and PC9 cells were treated without or with 0.01 , $0.1,1,10$ and $100 \mu \mathrm{M}$ cisplatin for $48 \mathrm{~h}$. Viable cells were analyzed using MTT assay as described in Materials and methods. Values are means \pm SEM of results from three independent experiments in triplicate. (B) The A549 cells were treated $0.5 \mu \mathrm{M}$ cisplatin combined with or without 6.25 and $25 \mu \mathrm{M}$ norcantharidin (NCTD) for $48 \mathrm{~h}$. (C) The PC9 cells were treated $0.1 \mu \mathrm{M}$ cisplatin combined with or without 6.25 and $25 \mu \mathrm{M}$ norcantharidin for $48 \mathrm{~h}$. Viable cells were analyzed using MTT assay as described in Materials and methods Values are means \pm SEM of results from three independent experiments in triplicate. Data were analyzed using Student's t-test; * $\mathrm{p}<0.05$, as compared to the value of control; ${ }^{\#} \mathrm{p}<0.05$, as compared to the value of cisplatin treatment alone at corresponding concentration.

though the proposed underlying mechanisms are controversial. In addition, it is noteworthy that apoptosis induced by norcantharidin was not obviously observed in the lung cancer cells until high concentration $(100 \mu \mathrm{M})$. These findings suggested that norcantharidin mainly exhibits cytostatic effects against lung cancer cells.

The signaling through EGFR is important in the regulation of proliferation and migration of lung cancer cells (4). This signaling pathway is regulated by phosphorylation modification of the cytosolic domain of EGFR through protein kinases and phosphatases (27). It has been reported that norcantharidin is a protein phosphatase 1 (PP1) and protein phosphatase $2 \mathrm{~A}$ (PP2A) inhibitor $(19,20)$. Thus, we tested whether EGFR is involved in the norcantharidin-induced cytotoxicity of human lung cancer cells. We used calyculin A, an inhibitor of protein phosphatase PP1 and PP2A, as a positive control for the effects of protein phosphatase inhibitor on the phosphorylated pattern of EGFR, and found that $5 \mathrm{nM}$ calyculin A treatments increased the phosporylated status of EGFR at Ser1046/1047, but decreased the phosphorylation at Tyr1068, Tyr1148 and
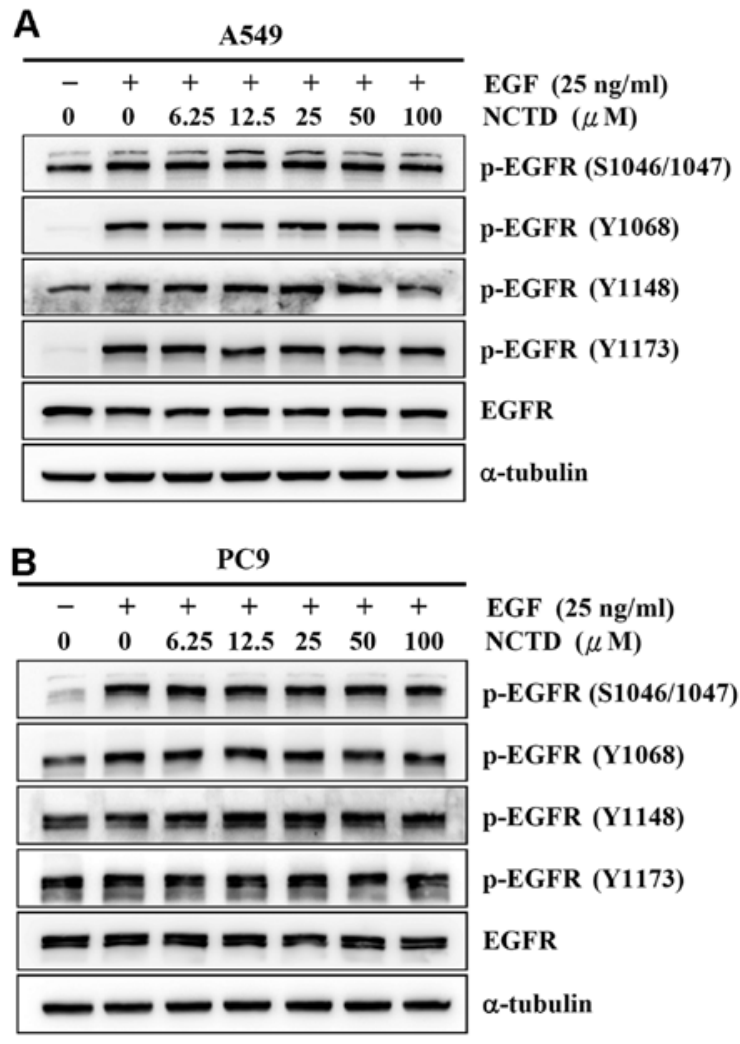

Figure 7. Effect of norcantharidin on phosphorylation of EGFR. The A549 (A) and PC9 (B) cells were grown under serum starvation for $24 \mathrm{~h}$ and then treated with $25 \mathrm{ng} / \mathrm{ml}$ EGF combined with $0,6.25,12.5,25,50$ and $100 \mu \mathrm{M}$ norcantharidin (NCTD) for $1 \mathrm{~h}$. The phosphorylation status of EGFR at pS1046/1047, pY1068, pY1148, and pY1173 sites were analyzed using western blotting as described in Materials and methods. Consistent results from three independent experiments were observed.

Tyr1173, respectively (data not shown). However, norcantharidin treatments did not obviously alter the EGF-stimulated phosphorylation status of the EGFRs in the two cell lines (Fig. 7). Moreover, the two cell lines with different EGFR mutation status have similar $\mathrm{IC}_{50}$ values for norcantharidin treatments (Fig. 1A), though the PC9 cells (EGFR mutationpositive) are more sensitive to gefitinib than the A549 cells (EGFR mutation-negative). These results suggested that EGFR might not be involved in the norcantharidin-induced anticancer effects against these two kinds of lung cancer cells.

In conclusion, we provide in vitro evidence in human lung cancer cell lines to suggest that norcantharidin retards cell growth, disturbs cell cycle progression, and represses cell migration, as well as enhances the anticancer effects of gefitinib and cisplatin.

\section{Acknowledgments}

We thank Ms. Shu-Hui Li for her excellent technical assistance. This work was partly supported by the grants V99E2-006 and V99E2-008 from Taipei Veterans General Hospital, a grant for the Center of Excellence for Cancer Research at Taipei Veterans General Hospital, the Department of Health (DOH99-TDC-111-007, DOH100-TDC-111-007, and DOH101-TDC-111-007), Executive Yuan, and a grant from Ministry of Education, Aim for the Top University Plan and 
the grants NSC97-2320-B-010-022-MY3 and NSC101-2320B-010-068-MY3 from the National Science Council, Taiwan, Republic of China.

\section{References}

1. Jemal A, Bray F, Center MM, Ferlay J, Ward E and Forman D: 2011. Global cancer statistics. CA Cancer J Clin 61: 69-90, 2011.

2. Ramalingam S and Belani C: Systemic chemotherapy for advanced non-small cell lung cancer: recent advances and future directions. Oncologist 13: 5-13, 2008.

3. Sharma SV, Bell DW, Settleman J and Haber DA: Epidermal growth factor receptor mutations in lung cancer. Nat Rev Cancer 7: 169-181, 2007.

4. Mendelsohn J: Blockade of receptors for growth factors: an anticancer therapy - the fourth annual Joseph H. Burchenal American Association of Cancer Research Clinical Research Award Lecture. Clin Cancer Res 6: 747-753, 2000.

5. Cohen MH, Williams GA, Sridhara R, Chen G, McGuinn WD Jr, Morse D, Abraham S, Rahman A, Liang C, Lostritto R, Baird A and Pazdur R: United States Food and Drug Administration Drug Approval summary: Gefitinib (ZD1839; Iressa) tablets. Clin Cancer Res 10: 1212-1218, 2004.

6. Wu JY, Shih JY, Chen KY, Yang CH, Yu CJ and Yang PC: Gefitinib therapy in patients with advanced non-small cell lung cancer with or without testing for epidermal growth factor receptor (EGFR) mutations. Medicine 90: 159-167, 2011.

7. Lacouture ME: Mechanisms of cutaneous toxicities to EGFR inhibitors. Nat Rev Cancer 6: 803-812, 2006.

8. Jiang H: Overview of gefitinib in non-small cell lung cancer: an Asian perspective. Jpn J Clin Oncol 39: 137-150, 2009.

9. Wang GS: Medical uses of mylabris in ancient China and recent studies. J Ethnopharmacol 26: 147-162, 1989.

10. Chen YN, Chen JC, Yin SC, Wang GS, Tsauer W, Hsu SF and Hsu SL: Effector mechanisms of norcantharidin-induced mitotic arrest and apoptosis in human hepatoma cells. Int J Cancer 100: $158-165,2002$

11. Hill TA, Stewart SG, Ackland SP, Gilbert J, Sauer B, Sakoff JA and McCluskey A: Norcantharimides, synthesis and anticancer activity: Synthesis of new norcantharidin analogues and their anticancer evaluation. Bioorg Med Chem 15: 6126-6134, 2007.

12. Fan YZ, Fu JY, Zhao ZM and Chen CQ: Inhibitory effect of norcantharidin on the growth of human gallbladder carcinoma GBC-SD cells in vitro. Hepatobiliary Pancreat Dis Int 6: 72-80, 2007.

13. Peng F, Wei YQ, Tian L, Yang L, Zhao X, Lu Y, Mao YQ, Kan B, Lei S, Wang GS, Jiang Y, Wang QR, Luo F, Zou LQ and Liu JY: Induction of apoptosis by norcantharidin in human colorectal carcinoma cell lines: involvement of the CD95 receptor/ligand J Cancer Res Clin Oncol 128: 223-230, 2002.

14. Liao HF, Su SL, Chen YJ, Chou CH and Kuo CD: Norcantharidin preferentially induces apoptosis in human leukemic Jurkat cells without affecting viability of normal blood mononuclear cells. Food Chem Toxicol 45: 1678-1687, 2007.
15. Chen YJ, Shieh CJ, Tsai TH, Kuo CD, Ho LT, Liu TY and Liao HF: Inhibitory effect of norcantharidin, a derivative compound from blister beetles, on tumor invasion and metastasis in CT26 colorectal adenocarcinoma cells. Anticancer Drugs 16: 293-299, 2005

16. Chen YJ, Tsai YM, Kuo CD, Ku KL, Shie HS and Liao HF: Norcantharidin is a small-molecule synthetic compound with anti-angiogenesis effect. Life Sci 85: 642-651, 2009.

17. Yang EB, Tang WY, Zhang K, Cheng LY and Mack PO: Norcantharidin inhibits growth of human HepG2 cell-transplanted tumor in nude mice and prolongs host survival. Cancer Lett 117: 93-98, 1997.

18. Fan YZ, Zhao ZM, Fu JY, Chen CQ and Sun W: Norcantharidin inhibits growth of human gallbladder carcinoma xenografted tumors in nude mice by inducing apoptosis and blocking the cell cycle in vivo. Hepatobiliary Pancreat Dis Int 9: 414-422, 2010.

19. Liu XH, Blazsek I, Comisso M, Legras S, Marion S, Quittet P, Anjo A, Wang GS and Misset JL: Effects of norcantharidin, a protein phosphatase type-2A inhibitor, on the growth of normal and malignant haemopoietic cells. Eur J Cancer 31 A: 953-963, 1995.

20. McCluskey A, Ackland SP, Gardiner E, Walkom CC and Sakoff JA: The inhibition of protein phosphatases 1 and 2A: a new target for rational anti-cancer drug design? Anticancer Drug Des 16: 291-303, 2001

21. Hill TA, Stewart SG, Sauer B, Gilbert J, Ackland SP, Sakoff JA and McCluskey A: Heterocyclic substituted cantharidin and norcantharidin analogues-synthesis, protein phosphatase (1 and 2A) inhibition, and anti-cancer activity. Bioorg Med Chem Lett 17: 3392-3397, 2007.

22. Wu CW, Ping YH, Yen JC, Chang CY, Wang SF, Yeh CL, Chi CW and Lee HC: Enhanced oxidative stress and aberrant mitochondrial biogenesis in human neuroblastoma SH-SY5Y cells during methamphetamine induced apoptosis. Toxicol Applied Pharmacol 220: 243-251,2007.

23. Luan J, Duan H, Liu Q, Yagasaki K and Zhang G: Inhibitory effects of norcantharidin against human lung cancer cell growth and migration. Cytotechnology 62: 349-355, 2010.

24. Hong CY, Huang SC, Lin SK, Lee JJ, Chueh LL, Lee CH, Lin JH and Hsiao M: Norcantharidin-induced post-G(2)/M apoptosis is dependent on wild-type p53 gene. Biochem Biophys Res Commun 276: 278-285, 2000.

25. Liao HF, Chen YJ, Chou CH, Wang FW and Kuo CD: Norcantharidin induces cell cycle arrest and inhibits progression of human leukemic Jurkat T cells through mitogen-activated protein kinase-mediated regulation of interleukin-2 production. Toxicol In Vitro 25: 206-212, 2011.

26. Yang PY, Chen MF, Kao YH, Hu DN, Chang FR and Wu YC: Norcantharidin induces apoptosis of breast cancer cells: involvement of activities of mitogen activated protein kinases and signal transducers and activators of transcription. Toxicol In Vitro 25: 699-707, 2011.

27. Millward TA, Zolnierowicz S and Hemmings BA: Regulation of protein kinase cascades by protein phosphatase $2 \mathrm{~A}$. Trends Biochem Sci 24: 186-191, 1999. 